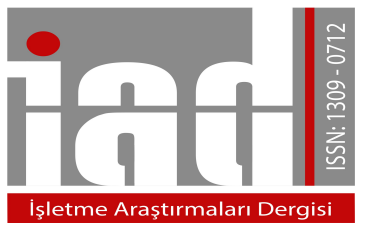

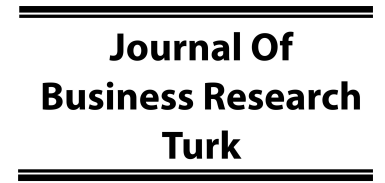

www.isarder.org

\title{
Innovation Capacity and Innovation Performance in Terms of Educational Level of Managers ${ }^{1}$
}

\author{
Fikret SÖZBILLIR \\ Artvin Çoruh University \\ Faculty of Economics and Administrative Science \\ Hopa, Artvin, Turkey \\ orcid.org.0000-0003-2665-1795 \\ fsozbilir08@hotmail.com
}

\begin{abstract}
The main aim of this research is to analyze whether the firm's innovation capacity and innovation performances differs according to the level of training/education of its managers as well as analyzing whether the capacity of innovation of the companies effects the innovation performances. To do this, the data was gathered by means of a questionnaire from 456 participating managers working in 274 firms listed among the top 500 companies in Turkey. The research hypotheses were tested by analyzing obtained data by making confirmatory factor analyses, correlations analysis, reliability analysis, one-way ANOVA analysis and regression with SPSS 24 software. As a result of the research, in terms of innovation performance, there is a difference between the managers who have master's degree and the managers who have other training/educational level. In addition to these, firm's innovation capacity significantly effects innovation performance in a positive way.
\end{abstract}

Keywords: Managers' Training/Education, Innovation Capability, Innovation Performance.

\section{Introduction}

Innovation is the most important factor in the survival of a company. Innovation is defined as "the intentional introduction and application within a job, work team or organization of ideas, processes, products or procedures which are new to that job, work team or organization and which are designed to benefit the job, the work team or the organization" (West \& Farr 1990: 9). A firm can increase its innovation capacity and innovate its products, services or processes by research and development (R\&D) and make it harder for competitors to imitate to them. Thus, the capacity and characteristics of $R \& D$ which is an important element of innovation capacity gives to the firm the

\footnotetext{
1 This paper is derived from the doctoral dissertation titled "The Relationship among Information Technologies, Knowledge Management and Innovation: An Empirical Study in Turkey" and Kahramanmaraş Sutcu Imam University Scientific Research Project no. 2013/1-17 D. I sincerely thank my dissertation and project supervisor, Assoc. Prof. Salih Yeşil for her significant contributions to this research.
} 
opportunity to execute the innovation program successfully (Cavusgil et al., 2003, p. $10)$. On the other hand, innovative performance focuses both on the technical aspects of innovation and on the offering of new products into the market (Zizlavsky, 2016: 819). Drucker (1954) argued that due to market characteristics are the short life cycle and high new product entry rate, innovation capacity is a critical element in achieving superior innovation performance. In this regard, innovation capacity is important for firms in complex and dynamic environment as competitive advantage factor (Yam et al., 2004 , p. 1123). Knowledge is a power and this power feeds the innovation. There are two types of knowledge: explicit and tacit knowledge and both of these are useful for innovation. However, tacit knowledge provided by vocational training have a critical role in the firm's innovation capacity because of its inability to be learn in a short time (Cavusgil et al., 2003, p. 10) and due to the inability to be conveyed in words or in writing (Polanyi, 1962, 1966; Nonaka, 1991, pp. 96-104; Nonaka \& Takeuchi, 1995, p. $62)$. Thus practical training is more strategic than theoretical education at school. There are also researches on the relationship between innovation and age (Frosch, 2011). Many researchers were determined that innovations emerged at middle ages (30-40 ages) after the accumulation of tacit and explicit knowledge through education at young age (Lehman, 1966, p. 266; Jones, 2010; Frosch, 2011, p. 415). Some researchers in their studies found that there is a common belief that older employees are less innovative than their younger co-workers. It is believed to that older employees are usually weak with regard to be flexibility, openness to novelty, and motivation $(\mathrm{Ng} \&$ Feldman, 2012; Rietzschel \& Zacher, 2017, pp. 1-4). Marital status is another demographic variable and previous findings are different from each other. According to some, the marital status of employees has a negative impact on innovation performance.

The aim of this article is to examine whether there is an impact of managers' training/education on innovation capacity and performance. Therefore, current and limited literature in this area briefly reviewed in order to determine findings of previous research and identify the scope of this research. Limited number of studies on the concept of managers' training/education and innovation capacity and performance in recent years gained interest among researchers within the business management fields. Due to the lack of enough studies on innovation capacity and innovation performance from training perspective in literature, there is an information gap in interaction between innovation capacity and innovation performance of the top 500 firms in Turkey. This study will fill a significant gap in the literature.

\section{Literature Review}

\subsection{Innovation Capacity and Training/Education}

Innovation capability is defined as "the way enterprises can generate innovative outputs" (Esterhuizen et al., 2012, p. 2). Kogut and Zander (1992, p. 391) emphasized that innovation is integrating capacity of a firm about bringing out new implementations from current knowledge. At the same time innovation capacity is the capability to develop new versions and make necessary changes in the direction of market demand. Innovation capacity is a factor that can be improved by working. Innovation capacity is the method and capacity of a firm to produce innovative output. The following factors indicate the level of innovation capacity of a firm: (i) product innovation; (ii) process innovation; (iii) investment in $\mathrm{R} \& \mathrm{D}$, and (iv) new distribution channels (Marques and Ferreira, 2009, p. 56). Previous researches were determined that innovation capacity 
emerged at middle ages (30-40 ages) after the accumulation of tacit and explicit knowledge through education at young age (Lehman, 1966, p. 266; Jones, 2010). Giuri et al., (2007, p. 1111) surveyed the 9017 inventors granted by the European Patent Office (PatVal-EU) between 1993 and 1997, located in France, Germany, Italy, Netherlands, Spain and the United Kingdom (EU6). They are found that there is a relationship between education and innovation capacity. On the other hand, it is argued that Liu et al. (2016) and Ng \& Feldman (2013) examined the impact of training on innovation capacity at Sierra Leone Agricultural Research Institute and their research results showed that training for innovation by collective action and multiple knowledge sources has a positive impact on innovation capacity and development value chains. Watson (2006) argued that education via information and communication technologies leads to improve innovation capacity. The following hypothesis were developed to test whether training/education has an impact on innovation capacity or not.

$\mathrm{H}_{1}$. Training/education has a significant and positive impact on innovation capacity

\subsection{Innovation Performance and Training/Education}

Innovation performance is defined as "the ability to transform innovation inputs into outputs, and thus the ability to transform innovation capability and effort into market implementation." (Zizlavsky, 2016, p. 818). Training is one of the factor has an impact on innovation performance. Some studies concluded that there is a relationship between training (or education) and innovation performance (Nazarov \& Akhmedjonov, 2012; Sözbilir, 2018). According to Frosch (2011, p. 416), education contributes to innovation performance. At the same time in his research, the negative correlation between innovation performances of low educated elderly workers and well-educated young people is misleading. This opinion implied that education has a positive effect on innovation performance. Acemoglu (1997) conducted that there is an interaction between innovation and training in his research. Boring (2017) examined the relationship between employee training (or education) and innovation activities, then he revealed that there is a positive relationship between the employee training, training method and innovation activities. In a study (Haq et al., 2017) organizational tenure has moderated effect negatively on innovation performance, and employees with lesser organizational tenure were found to be more innovative. Thus, following hypotheses developed to test whether education have an impact on innovation capacity.

$\mathrm{H}_{2}$. Training/education has a significant and positive impact on innovation performance.

\subsection{Impact of Innovation Capacity on Innovation Performance}

Prajogo and Ahmed (2006, p. 506) defined the innovation capacity as "the organizational potential to innovate, which is determined by the skills and strengths in basic R\&D and technology." Also, firm-specific values such as inimitable resources, patents, trademarks, original production methods, technology and experienced engineers, are important source for innovation capacity. Rajapathirana and Hui (2018, p. 45) explained the innovation performance as "combination of assets and resources." Prajogo and Ahmed (2006, p. 506) surveyed on 194 managers of Australian firms and concluded that there is a significant and strong relationship between innovation capacity and innovation performance. In their study on 379 senior managers of insurance 
companies in Sri Lanka, Rajapathirana and Hui (2018), found the significant link between innovation capability and innovation performance. Büyükbeşe and Yıldiz (2017) conducted a research in 160 different companies that are located in Gaziantep Organized Industrial Zone and results of their research showed that innovation capacity of companies significantly and positively affected their innovation performance. Following hypothesis developed to test whether innovation capacity has an impact on innovation performance or not. performance

$\mathrm{H}_{3}$. Innovation capacity has a significantly and positively impact on innovation

\section{Methodology}

\subsection{Sample Design}

This study was conducted in the top 500 companies operating in Turkey because of these large-scale firms are mature and knowledge base firms and they have more opportunities to develop innovative solutions and more conscious of gaining competitive advantage. Data for the empirical study was collected through a questionnaire from 456 managers of 274 companies which are listed in top 500 companies in Turkey. The response rate was $18.3 \%$ on the manager basis and $54.8 \%$ on the firm basis.

\subsection{Measures and Data Analysis}

The questionnaire composed of three parts; demographic characteristic, innovation capacity, and innovation performance. Demographic characteristic survey of the managers that includes five items (gender, age, education, marital status, and tenure). Innovation capacity was measured using six-item scale adapted from the study of Calantone et al. (2002). Also innovation performance was measured using a eightitem scale adapted from Prajogo and Ahmed (2006) and one item was added for this study, thus total item number was nine. Both of the innovation scales were used as Likert type (Innovation capacity: $1=$ Worst in industry, 5=Best in industry; Innovation performance: $1=$ Strongly disagree, $5=$ Strongly agree). SPSS 24.0 as well as descriptive statistics, One-Way ANOVA and Simple Linear Regression analyses were used to test the research hypothesis.

\section{Results}

The findings about demographic characteristics of respondents are shown in Table 1. The sample was mostly male $(75,7 \%)$ with remaining $24,3 \%$ female. Married respondents are majority $(57.5 \%)$. Most of the managers are between 25 and 34 years old (53.5\%). Regarding education level, 3.3\% described their education as high school and below, $12.1 \%$ vocational junior college, $49.3 \%$ bachelor degree, $34.4 \%$ master, and 0.9 doctoral degree. In terms of tenure (workplace experience), as follows: up to five years $(19.7 \%)$, from three to five years $(32.0 \%)$, from six to nine years $(19.3 \%)$, from ten to twelve years (14.9\%), and 13 years and over (14.1\%). Regarding education level, $69.2 \%$ described their education as bachelor degree; $11.0 \%$ master; $6.6 \%$ vocational junior college; $13.2 \%$ high school or below. On the other hand, companies were categorized by number of employee: below 250 employees (8.3\%), 250-500 employees (21.5\%), 501-1000 employees (25.9\%), 1001-2000 employees (18.4\%), 2001-3000 employees (15.1\%), and 3001 employees and over (10.8\%). 
Table 1. Demographic Characteristics of Respondents

\begin{tabular}{|c|c|c|c|c|c|}
\hline Variables & Frequency & $\begin{array}{c}\text { Percentage } \\
(\%)\end{array}$ & Variables & Frequency & $\begin{array}{c}\text { Percentage } \\
(\%)\end{array}$ \\
\hline Gender & & & Marital status & & \\
\hline Female & 111 & 24.3 & Married & 262 & 57.5 \\
\hline Male & 345 & 75.7 & Single & 194 & 42.5 \\
\hline Total & 456 & 100.0 & Total & 456 & 100.0 \\
\hline Education & & & Age & & \\
\hline High school or below & 15 & 3.3 & Below 25 & 28 & 6.1 \\
\hline Voc. Junior College & 55 & 12.1 & $25-34$ & 244 & 53.5 \\
\hline Bachelor degree & 225 & 49.3 & $35-44$ & 141 & 30.9 \\
\hline Master & 157 & 34.4 & $45-54$ & 38 & 8.3 \\
\hline Doctorate & 4 & 0.9 & 55 and over & 5 & 1.1 \\
\hline Total & 456 & 100.0 & Total & 456 & 100.0 \\
\hline Tenure & & & $\begin{array}{l}\text { Employee Number in } \\
\text { Companies }\end{array}$ & & \\
\hline Below 3 years & 90 & 19.7 & Below 250 & 38 & 8.3 \\
\hline $3-5$ & 146 & 32.0 & $250-500$ & 98 & 21.5 \\
\hline $6-9$ & 88 & 19.3 & $501-1000$ & 118 & 25.9 \\
\hline $10-12$ & 68 & 14.9 & $1001-2000$ & 84 & 18.4 \\
\hline $13-15$ & 25 & 5.5 & $2001-3000$ & 69 & 15.1 \\
\hline $16-20$ & 25 & 5.5 & $3001-4000$ & 22 & 4.9 \\
\hline $21-25$ & 7 & 1.6 & $4001-5000$ & 4 & 0.9 \\
\hline 26 years and over & 7 & 1.5 & 5001 and over & 23 & 5.0 \\
\hline Total & 456 & 100.0 & Total & 456 & 100.0 \\
\hline
\end{tabular}

\subsection{Analysis Related to Reliability and Validity of the Research}

The reliability of research scale in the survey is measured by Cronbach's Alpha and values of all scales were over 70 reflecting an acceptable level (Nunnally. 1978). Confirmative factor analysis was used to determine validity of this study. KaiserMeyer-Olkin (KMO) values are over .70 reflecting a good level and also common variances of variables are over .50. highly good. As a result of Bartlett's test of sphericity all scales in the survey are statistically significant at .000 level and it shows that samples are sufficient to analysis (Sharma, 1996). The results of reliability and validity analysis of scales are shown in Table 2.

Table 2. Results of Reliability and Validity Analysis of Research

\begin{tabular}{lcccccccc}
\hline Scales & $\begin{array}{c}\text { Item Cronbach's } \\
\text { Nu. }\end{array}$ & $\begin{array}{c}\text { Factor } \\
\text { Alpha }(\boldsymbol{\alpha})\end{array}$ & $\begin{array}{c}\text { Loading* } \\
\text { LMO }\end{array}$ & $\begin{array}{c}\text { Appr. } \\
\boldsymbol{\chi}^{\mathbf{2 * *}}\end{array}$ & df & $\begin{array}{c}\text { Variance } \\
\text { \% }\end{array}$ & (Sig./p) \\
\hline $\begin{array}{l}\text { Innovation } \\
\text { Capacity }\end{array}$ & 6 & .749 & $.578-.823$ & .745 & 713,257 & 15 & 45,805 & .000 \\
$\begin{array}{l}\text { Innovation } \\
\text { Performance }\end{array}$ & 9 & .815 & $.547-.846$ & .829 & 1.383 & 36 & 58,097 & .000 \\
\hline
\end{tabular}

* Indicates factor loading of items from lowest to highest; ** Approximate Chi-Square. 


\subsection{Correlation Analysis}

Table 3 presents the descriptive results for innovation capacity and innovation performance. The correlations between constructs are significant. Training/education is significantly and positively but low level correlated with perceived innovation capacity $(r=.134, p<.01)$ and innovation performance $(r=.114, p<.05)$. Also, there is a positive correlation between innovation capacity and innovation performance $(r=.539$, $p<.01)$.

Table 3. Means, Standard Deviations, and Inter-Correlations for Variables

\begin{tabular}{lccccc}
\hline \multicolumn{1}{c}{ Variables } & M & SD & $\mathbf{1}$ & $\mathbf{2}$ & $\mathbf{3}$ \\
\hline 1. Training/Education & 3.18 & .78 & 1 & & \\
2. Innovation Capacity & 4.17 & .51 & $.134^{* *}$ & 1 & $.539^{* *}$ \\
3. Innovation Performance & 4.22 & .45 & $.114^{*}$ & 1 \\
\hline
\end{tabular}

**. Correlation is significant at the 0.01 level (2-tailed). $(\mathrm{N}=456)$

*. Correlation is significant at the 0.05 level (2-tailed).

$N S=$ No Significant

\subsection{Descriptive statistics}

Descriptive statistics of participants' innovation capacity perceptions are shown in Table 4 and innovation performance perceptions are shown in Table 5. Participants' evaluation of the innovation capacity and innovation performance was tried to be evaluated with a scale consisting of 6 items and Likert type questions. Evaluation range determined between 1 and 5 ( $1=$ Strongly disagree, $2=$ Disagree, $3=$ Agee moderately, $4=$ Agree, $5=$ Strongly agree).

Likert type questions in the questionnaire were evaluated by taking into consider their averages. The intervals in Table 4 was used to evaluate the averages of innovation capacity and data in Table 5 was used to evaluate the averages of innovation performance. Taking the assumption that the intervals are equal, the score for the arithmetic mean the coefficient of variation was found to be 0.80 [Interval Score $=$ (Highest-Lowest) $/ 5=(5-1) / 5=0.80]$. This value, was added to 1.00 , which is the lowest value of the answer codes, and later followed by additions to the next values, thus evaluation intervals was obtained (Küçükali, 2016, p. 538). Accordingly, the evaluation intervals of the arithmetic mean are: $1.00-1.80=$ very low; $1.81-2.60=$ low; 2.61-3.40 = medium; 3.41-4.20 = high; 4.21-5.00 = very high.

Mean values of participants' perceptions on innovation capacity were shown in Table 4. The scale item "our company frequently tries out new ideas" has the highest mean value $(M=4.25)$ while "our company is often the first to market with new products and services" was determined as item has the lowest mean value $(M=4.12)$. These results indicated that managers, working for top 500 companies in Turkey, have very high level perception in innovation capacity about their companies. 
Table 4. Innovation capacity items and descriptive statistics

\begin{tabular}{|c|c|c|c|c|c|c|c|c|c|c|}
\hline Scale Items & & M/SD & Level & $F / \%$ & 1 & 2 & 3 & 4 & 5 & Total \\
\hline \multirow{2}{*}{$\begin{array}{l}\text { Our company frequently tries } \\
\text { out new ideas }\end{array}$} & $\mathrm{M}$ & 4.25 & \multirow{2}{*}{$\begin{array}{l}\text { Very } \\
\text { high }\end{array}$} & $\mathrm{F}$ & 3 & 11 & 49 & 201 & 192 & 456 \\
\hline & $\mathrm{SD}$ & 0.79 & & $\%$ & 0.7 & 2.4 & 10.7 & 44.1 & 42.1 & 100 \\
\hline \multirow{2}{*}{$\begin{array}{l}\text { Our company seeks out new } \\
\text { ways to do things }\end{array}$} & $\mathrm{M}$ & 4.19 & \multirow{2}{*}{ High } & $\mathrm{F}$ & 0 & 4 & 30 & 297 & 125 & 456 \\
\hline & $\mathrm{SD}$ & 0.58 & & $\%$ & 0 & 0.9 & 6.6 & 65.1 & 27.4 & 100 \\
\hline \multirow{2}{*}{$\begin{array}{l}\text { Our company is creative in its } \\
\text { methods of operation }\end{array}$} & $\mathrm{M}$ & 4.21 & \multirow{2}{*}{$\begin{array}{l}\text { Very } \\
\text { high }\end{array}$} & $\mathrm{F}$ & 0 & 4 & 51 & 247 & 154 & 456 \\
\hline & $\mathrm{SD}$ & 0.66 & & $\%$ & 0 & 0.9 & 11.2 & 54.2 & 33.8 & 100 \\
\hline \multirow{4}{*}{$\begin{array}{l}\text { Our company is often the first } \\
\text { to market with new products } \\
\text { and services. } \\
\text { Innovation in our company is } \\
\text { perceived as too risky and is } \\
\text { resisted }\end{array}$} & $\mathrm{M}$ & 4.12 & \multirow{2}{*}{ High } & $\mathrm{F}$ & 2 & 15 & 65 & 222 & 152 & 456 \\
\hline & $\mathrm{SD}$ & 0.79 & & $\%$ & 0.4 & 3.3 & 13.7 & 48.8 & 33.3 & 100 \\
\hline & $\mathrm{M}$ & 4.07 & \multirow{2}{*}{ High } & $\mathrm{F}$ & 12 & 23 & 50 & 206 & 165 & 456 \\
\hline & SD & 0.95 & & $\%$ & 2.6 & 5.0 & 11.0 & 45.2 & 36.2 & 100 \\
\hline \multirow[t]{2}{*}{$\begin{array}{l}\text { Our new product introduction } \\
\text { has increased over the last } 5 \\
\text { years }\end{array}$} & $\mathrm{M}$ & 4.18 & High & $\mathrm{F}$ & 2 & 15 & 50 & 221 & 167 & 455 \\
\hline & SD & 0.79 & & $\%$ & 0.4 & 3.3 & 11.0 & 48.5 & 36.6 & 100 \\
\hline
\end{tabular}

$\mathrm{M}=$ Mean, $\mathrm{SD}=$ Standard Deviation, $\mathrm{F}=$ Frequency,

( $1=$ Strongly disagree, $2=$ Disagree, $3=$ Agee moderately, 4=Agree, $5=$ Strongly agree $)$

Also, mean values of participants' perceptions on innovation performance were shown in Table 5. The scale item "the updatedness or novelty of the technology used in our processes" has the highest mean value $(M=4.30)$ while "the number of new products our firm has introduced to the market" was determined as item has the lowest mean value $(M=4.16)$. It is concluded from descriptive statistics that managers, working for top 500 companies in Turkey, have very high level perception in innovation performance about their companies.

Table 5. Innovation performance items and descriptive statistics

\begin{tabular}{|c|c|c|c|c|c|c|c|c|c|c|}
\hline sal & & $\mathbf{M} / \mathbf{S D}$ & Level & $F / \%$ & 1 & 2 & 3 & 4 & 5 & Total \\
\hline \multirow{2}{*}{$\begin{array}{l}\text { The level of newness (novelty) } \\
\text { of our firm's new products. }\end{array}$} & $\mathrm{M}$ & 27 & \multirow{2}{*}{$\begin{array}{l}\text { Very } \\
\text { high }\end{array}$} & 1 & 0 & 6 & 17 & 243 & 170 & 56 \\
\hline & SD & 66 & & $\%$ & 0 & 1.3 & 1 & .1 & 7.3 & 00 \\
\hline \multirow{2}{*}{$\begin{array}{l}\text { The use of latest technological } \\
\text { innovations in our new } \\
\text { products. }\end{array}$} & $\mathrm{M}$ & 21 & & $\mathrm{~F}$ & 0 & 1 & 55 & 5 & 55 & 56 \\
\hline & $\mathrm{SD}$ & 0.65 & & $\%$ & 0 & & 1 & 53.7 & 34.0 & 00 \\
\hline \multirow{2}{*}{$\begin{array}{l}\text { The speed of our new product } \\
\text { development. }\end{array}$} & th & & \multirow{2}{*}{$\begin{array}{l}\text { Very } \\
\text { high }\end{array}$} & 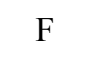 & 1 & & & & & 56 \\
\hline & D & 0.75 & & $\%$ & ת & 2.2 & & 49.1 & 36.2 & 100 \\
\hline \multirow{4}{*}{$\begin{array}{l}\text { The number of new products } \\
\text { our firm has introduced to the } \\
\text { market. } \\
\text { (In variety) In terms of the } \\
\text { number of our firm's new } \\
\text { products first entering to the } \\
\text { market. }\end{array}$} & $\mathrm{M}$ & 4.16 & \multirow[b]{2}{*}{ High } & $\mathrm{F}$ & & 0 & & & 10 & 56 \\
\hline & SD & 0.69 & & $\%$ & 0.2 & 1.8 & 10.7 & 56.4 & 30.7 & 100 \\
\hline & $\mathrm{M}$ & 4.19 & \multirow{2}{*}{$\begin{array}{l}\text { Very } \\
\text { high }\end{array}$} & $\mathrm{F}$ & 1 & 11 & 44 & 244 & 6 & 456 \\
\hline & SD & 0.72 & & $\%$ & 0.2 & 2.4 & & 53.3 & 34.2 & 100 \\
\hline \multirow{2}{*}{$\begin{array}{l}\text { The technological } \\
\text { competitiveness of our } \\
\text { company. }\end{array}$} & M & 4.23 & \multirow{2}{*}{$\begin{array}{l}\text { Very } \\
\text { high }\end{array}$} & $\mathrm{F}$ & 0 & 7 & 47 & 236 & 6 & 456 \\
\hline & SD & 0 & & $\%$ & 0 & 1.5 & 10.3 & 8 & .4 & 0 \\
\hline The speed with which we & M & 4.25 & Very & $\mathrm{F}$ & 0 & 12 & 45 & 218 & 181 & 456 \\
\hline
\end{tabular}




\begin{tabular}{lcccccccccc}
\hline $\begin{array}{l}\text { adopt the latest technological } \\
\text { innovations in our processes. }\end{array}$ & $\mathrm{SD}$ & 0.74 & high & $\%$ & 0 & 2.6 & 9.9 & 47.6 & 39.7 & 100 \\
$\begin{array}{l}\text { The updatedness or novelty of } \\
\text { the technology used in our }\end{array}$ & $\mathrm{M}$ & 4.30 & Very & $\mathrm{F}$ & 0 & 3 & 46 & 217 & 190 & 456 \\
$\begin{array}{l}\text { processes. } \\
\begin{array}{l}\text { The rate of change in our } \\
\text { processes. techniques and }\end{array}\end{array}$ & $\mathrm{SD}$ & 0.67 & high & $\%$ & 0 & 0.7 & 10.1 & 47.4 & 41.7 & 100 \\
technology & 4.22 & $\begin{array}{l}\text { Very } \\
\text { high }\end{array}$ & $\mathrm{F}$ & 4 & 5 & 44 & 238 & 165 & 456 \\
& $\mathrm{SD}$ & 0.73 & & $\%$ & 0.9 & 1.1 & 9.6 & 52.0 & 36.2 & 100 \\
\hline
\end{tabular}

$\mathrm{M}=$ Mean, $\mathrm{SD}=$ Standard Deviation, $\mathrm{F}=$ Frequency,

( 1 =Worst in industry, $2=$ Bad in industry, $3=$ Good Moderately, $4=$ Good in industry, $5=$ Best in industry)

\subsection{One-Way ANOVA}

One-way analysis of variance (ANOVA) was conducted to test whether there is a significant difference between the education of companies' managers and their perception level of innovation capacity and innovation performance separately and results of the analysis were shown in Table 6. Training/education consisted of five levels (high school or below, associate degree, bachelor degree, master, and doctorate).

According to the results of variance analysis in Table 6, there is a significant difference between educational level of managers and innovation capacity $[\mathrm{F}(4,451)=$ $5.357, p<.01]$ and the innovation performance $[\mathrm{F}(4,451)=2.558, p<.05]$. A post-hoc test using Tukey HSD test was conducted to compare the mean of the five groups. Tukey HSD test results indicated that managers with master education level had significantly higher innovation capacity scores than high school $(M D=.46, p<.05)$ and bachelor's degree $(M D=.17, p<.05)$. At the same time the managers with master education level had significantly higher innovation performance scores than managers with bachelor degree $(M D=.14, p<.05)$. However, there is no significant mean difference between the managers with associate degree and doctorate. These results showed that Training/Education has impact on innovation capacity and innovation performance. Thus first and second hypotheses; $\left(\mathrm{H}_{1}\right)$ "Training/education has a significant and positive impact on innovation capacity" and $\left(\mathrm{H}_{2}\right)$ "Training/education has a significant and positive impact on innovation performance" were accepted. Findings from previous studies supported this work (i.e. Giuri et al., 2007; Liu et al., 2016; Ng \& Feldman, 2013; Watson, 2006).

Table 6. One-way analysis of variance (ANOVA) analysis of the impact of training/education on innovation capacity and performance separately

\begin{tabular}{lcccccc}
\hline \multicolumn{1}{c}{$\begin{array}{c}\text { Variance } \\
\text { Source }\end{array}$} & $\begin{array}{c}\text { Sum of } \\
\text { Square }\end{array}$ & df & Mean Square & F & p & $\begin{array}{c}\text { Significant } \\
\text { Difference }\end{array}$ \\
\hline Between groups & 5.453 & 4 & 1.363 & \\
Within groups & 114.759 & 451 & .254 & 5.357 & .000 & Yes \\
Total & 120.212 & 455 & & & \\
\hline \multicolumn{7}{c}{ Innovation Capacity } \\
\hline Between groups & 2.008 & 4 & .502 & & \\
Within groups & 88.504 & 451 & .196 & & Yes \\
Total & 90.512 & 455 & & & \\
\hline N $=456$ & & & & & \\
\end{tabular}




\subsection{Simple Linear Regression}

Simply linear regression analysis was conducted to determine that whether innovation capacity has impact on innovation performance or not. The results showed that innovation capacity as control variable contributed positively and significantly to the prediction of innovation performance $\left(\mathrm{R}^{2}=.291, p<.01\right)$. Thus, third hypothesis $\left(\mathrm{H}_{3}\right.$ : Innovation capacity has a significantly and positively impact on innovation performance) was accepted. Adjusted $\mathrm{R}^{2}$ value indicates that $29.1 \%$ of change in the innovation performance is explained by the innovation capacity. Standard beta value indicates that 1 unit change in innovation capacity increases the innovation performance by 0.539 unit. The regression analysis results are shown in Table 7.

Table 7. Simply Linear Regression Analysis Results

\begin{tabular}{lllllllll}
\hline $\begin{array}{l}\text { Independent } \\
\text { Variable }\end{array}$ & $\mathbf{B}$ & $\mathbf{S E}$ & $\boldsymbol{\beta}$ & $\mathbf{F}$ & $\mathbf{R}^{2}$ & $\mathbf{t}$ & $\mathbf{p}$ & $\mathbf{C I}$ \\
\hline Innovation Capacity & .468 & .034 & .539 & 185.980 & .291 & 13.637 & .000 & 14.3 \\
\hline
\end{tabular}

Dependent variable $=$ Innovation Performance; $\mathrm{CI}=$ Condition Index.

\section{Discussion and Conclusion}

In this study, it was examined that firms how improve their innovation capacity and innovation performance by the training of the managers or employing well trained managers. Also how impact of innovation capacity on innovation performance. Empirical data which were obtained from the 456 managers working in biggest firms in Turkey was used in this research. Three working hypotheses are presented, which are denoted $\mathrm{H} 1, \mathrm{H}_{2}$ and $\mathrm{H}_{3}$ and tested with the One-Way ANOVA and regression analyses. $\mathrm{H}_{1}$ states that training/education has a significant and positive impact on innovation capacity and $\mathrm{H}_{2}$ states that training / education has a significant and positive impact on innovation performance. One-Way ANOVA analyses results revealed that training/education has a significant and positive impact on innovation capacity $(\mathrm{F}=$ $2.558, p<.05)$ and innovation performance $(\mathrm{F}=5.357, p<.001)$. In this study, also determined that innovation capacity has a significant and positive impact on innovation performance $(\beta=.539 ; p<.001)$. Therefore, the results supported $\mathrm{H}_{1}, \mathrm{H}_{2}$, and $\mathrm{H}_{3}$. Giuri et al. (2007: 1111) found that there is a relationship between education and innovation capacity. Ng and Feldman (2013) and Liu et al. (2016) determined that training has impact on innovation capacity. Previous studies also support first hypothesis $\left(\mathrm{H}_{1}\right)$. Second hypothesis of this study $\left(\mathrm{H}_{2}\right)$ was supported by earlier empirical studies that investigated the impact of training on innovation performance (Acemoglu, 1997; Frosch, 2011, p. 416; Nazarov \& Akhmedjonov, 2012; Boring, 2017; Sözbilir, 2018). Finally, some studies concluded that innovation capacity has impact on innovation performance (Prajogo \& Ahmed, 2006, p. 506; Büyükbeşe \& Y1ld1z, 2017; Rajapathirana \& Hui, 2018). These results verified third hypothesis $\left(\mathrm{H}_{3}\right)$ of the research.

This study indicates that contribution of the educated managers who can generate new ideas and develop innovative solutions for a firm that wants to improve their innovation capacity and innovation performance. Post hoc (Tukey HSD) test results showed that master level managers have higher innovation capacity and innovation performance than managers at other levels of education. Innovation capacity is another factor that boosts innovation performance. The innovation capacity of firms enables to 
them search out new systems, develop new product and services quickly and put on market. Thus, firms can gain sustainable competitive advantage. (Rajapathirana \& Hui, 2018 , p. 45). There is a limitation of this study that the sample of this study is composed of the firm managers. Whereas a study involving sampling of all firm employees allows for a more general results.

\section{References}

Acemoglu, D. (1997). Training and Innovation in an Imperfect Labour Market. Review of Economic Studies, 64, 445-464.

Akcigit, U., Grigsby, J., \& Nicholas, T. (2017). The Rise of American Ingenuity: Innovation and Inventors of the Golden Age. Working Paper 17-063, NBER.

Boring, P. (2017). The relationship between training and innovation activities in enterprises. International Journal of Training and Development, 21(2), 123-129.

Büyükbeşe, T. \& Yıldız, B. (2017). The Effect of Innovation Capacity on Innovation Performance on Companies, 3(10), 130-137.

Calantone, R. J., Cavusgil, S. T. \& Zhao, Y. (2002). Learning orientation, firm innovation capability, and firm performance. Industrial Marketing Management, 31(6), 515-24.

Cavusgil, S. T., Calantone, R. J., \& Zhoa, Y. (2003). Tacit Knowledge Transfer and Firm Innovation Capability, Journal of Business and Industrial Marketing, 18(1), 6-21.

Drucker, P. F. (1954). The Practice of Management, New York: Harper and Row Publishers Inc.

Esterhuizen, D., Schutte, C. \& Du Toit, A. (2012). A knowledge management framework to grow innovation capability maturity. SA Journal of Information Management, 14(1), Art. \#495, 10 pages. http://dx.doi.org/10.4102/ sajim.v14i1.495

Gboku, M. L. S. \& Bebeley, J. F. (2016). Training for innovation: capacity building in agricultural research in post-war Sierra Leone. International Journal of Training and Development 20(2), 140-151

Ferreira, J.J.M., Fernandes, C.I. \& Raposo, M.L. (2017). The Effects of Location on Firm Innovation Capacity. Journal of the Knowledge Economy, 8(1), 77-96.

Frosch, K. H. (2011). Workforce Age and Innovation: A Literature Survey. International Journal of Management Reviews, 13, 414-430. DOI: 10.1111/j.1468-2370.2011.00298.x

Giuri, P., Mariani, M., Brusoni, S., Crespi, G., Francoz, D., \& Gambardella, A. (2007). Inventors and invention processes in Europe: Results from the PatVal-EU survey. Research Policy 36(8), 1107-1127. doi:10.1016/j.respol.2007.07.008

Haq, A. M., Usman, M., \& Hussain, J. (2017). Enhancing Employee Innovative Behavior: The Moderating Effects of Organizational Tenure. Pakistan Journal of Commerce and Social Sciences, 11(3), 814-832 
Jones, B. F. (2010). Age and Great Invention. Review of Economics and Statistics, 92(1), 1-14. https://doi.org/10.1162/rest.2009.11724

Kogut, B. \& Zander, U. (1992). "Knowledge of the firm, combinative capabilities, and the replication of technology", Organization Science, Vol. 3, No. 3, pp. 383-397.

Küçükali, A. (2016). Social Media Usage of College Students: The Case of Atatürk University (Üniversite Öğrencilerinin Sosyal Medya Kullanımı: Atatürk Üniversitesi Örneği). Bartın Üniversitesi I.I.I.B.F. Dergisi, 7(13), 531-546.

Lehman, H. (1966). The most creative years of engineers and other technologists. Journal of Genetic Psychology, 108, 263-277.

Lindberg, M. \& Berglund, K-E. (2016). Gendered social innovation - a new research stream for gender inclusive innovation policy, research and practice. In book: Research Handbook on Gender and Innovation, Edward Elgar Publishing, Editors: G. A. Alsos, U. Hytti, E. Ljunggren, pp.214-228

Liu, Z., Ge, L., Peng, W. (2016). How organizational tenure affects innovative behavior?: The role of culture difference and status determinants, Nankai Business Review International, 7(1), 99-126, https://doi.org/10.1108/NBRI-012016-0001

Marques, C. S. \& Ferreira, J. (2009). SME Innovative Capacity, Competitive Advantage and Performance in a 'Traditional' Industrial Region of Portugal. Journal of Technology Management \& Innovation, 4(4), 53-68. http://dx.doi.org/10.4067/S0718-27242009000400005

Nazarov, Z. \& Akhmedjonov, A. (2012) Education, On-the-Job Training, and Innovation in Transition Economies, Eastern European Economics, 50(6), 28-56. http://dx.doi.org/10.2753/EEE0012-8775500602

Ng, T. W. H. \& Feldman, D. C. (2012). Evaluating six common stereotypes about older workers with meta-analytical data. Personnel Psychology, 65, 821-858.

Ng, T.W.H. \& Feldman, D. C. (2013). A meta-analysis of the relationships of age and tenure with innovation-related behaviour. Journal of Occupational and Organizational Psychology, 86(4,) 585-616. DOI: 10.1111/joop.12031

Nonaka, I. (1991), “The knowledge-creating company", Harvard Business Review, 69, 96-104.

Nonaka, I. \& Takeuchi, H. (1995). The Knowledge-Creating Company: How Japanese Companies Create the Dynamics of Innovation, USA: Oxford University Press.

Nunnally, J.C. (1978) Psychometric Theory, McGraw-Hill, New York.

Pecis, L. (2016). Doing and undoing gender in innovation: Femininities and masculinities in innovation processes. Human Relations, 69(11), 2117-2140. doi:10.1177/0018726716634445

Prajogo, D. I. \& Ahmed, P. K. (2006). Relationships between innovation stimulus, innovation capacity, and innovation performance. $R \& D$ Management 36(5), 499515.

Polanyi, M. (1962). Personal Knowledge: Towards a Post-critical Philosophy, Chicago: Routledge and Kogan Paul. 
Polanyi, M. (1966). The Tacit Dimension, New York: Doubleday \& Company Inc.

Schneider, L. (2008). Alterung und technologisches Innovationspotential - Eine Linked-Employer-Employee-Analyse (Ageing and technological Innovativeness: A linked employer-employee analysis). Zeitschrift für Bevölkerungswissenschaft, 33, 37-54. DOI 10.1007/s12523-008-0004-z

Sharma, S. (1996). Applied Multivariate Techniques, New York: John Wiley and Sons Inc.

Sözbilir, F. (2018). İşbaşı Eğitim Uygulamaları, Öz-Yeterlilik ve Yenilikçilik Davranışı Arasındaki İlişki (A Relationship between On-The-Job Training Practices, SelfEfficacy, and Innovative Behavior). Journal of Business Research-Türk, 10(1), 119-142.

Rajapathirana, R. P. J. and Hui, Y. (2018). Relationship between innovation capability, innovation type, and firm performance. Journal of Innovation \& Knowledge, 3, 44-55. doi: 10.1016/j.jik.2017.06.002.

Rietzschel, E.F. \& Zacher, H. (2017). Workplace Creativity, Innovation, and Age. In: Pachana N.A. (eds) Encyclopedia of Geropsychology. Springer, Singapore.

Watson, D. (2006). Understanding the relationship between ICT and education means exploring innovation and change. Education and Information Technologies (2006) 11(3-4), 199-216. DOI 10.1007/s10639-006-9016-2

West, M., \& Farr, J. L. (1990). Innovation at work. In M. A. West, \& J. L. Farr (Eds.), Innovation and creativity at work: psychological and organizational strategies. (pp. 3-13). Chichester: John Wiley \& Sons, Ltd.

Yam, R., Guan, J.C., Pun, K.F. \& Tang, E.P. (2004). An audit of technological innovation capabilities in Chinese firms: Some empirical findings in Beijing, China. Research Policy, 33(8), 1123-1140.

Zizlavsky, O. (2016). Innovation performance measurement: research into Czech business practice, Economic Research-Ekonomska Istraživanja, 29(1), 816-838, DOI: 10.1080/1331677X.2016.1235983. 